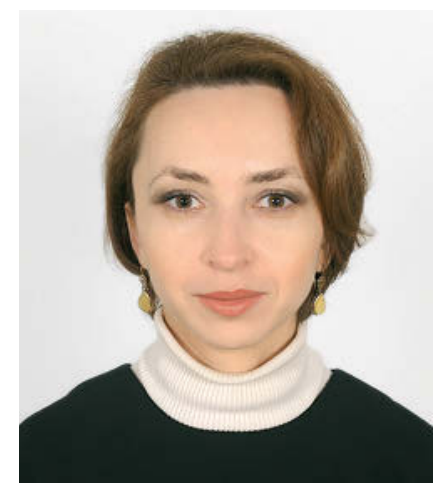

\author{
Olha Filyk, Yaroslav Pidhirnyy
}

\title{
PHOSPHORUS AND MAGNESIUM DISORDERS IN CRITICALLY ILL MECHANICALLY VENTILATED CHILDREN: THE PROSPECTIVE COHORT OBSERVATIONAL STUDY
}

\section{Department of Anesthesiology and Intensive Care, Danylo Halytsky Lviv National Medical University, Lviv, Ukraine}

\section{Abstract.}

Background. Phosphate and magnesium disorders frequently develop in critically ill patients during the course of stay in paediatric intensive care unit.

Objectives. The aim of this study was to investigate the prevalence of hypophosphatemia and low level of magnesium in children with acute respiratory failure. The study hypothesis was that the duration of mechanical ventilation and stay in PICU in children depend on the presence of electrolyte disorders.

Setting. Tertiary children's hospital, Department of Anesthesiology and Intensive Care, Danylo Halytsky Lviv National Medical University; Department of Anesthesiology and Intensive Care, Lviv Regional Children Hospital "OCHMATDYT", Ukraine, July 2018 - July 2019.

Patients. Children aged 1 month -1 year, who needed invasive mechanical ventilation.

Intervention. Measurement levels of phosphorus and magnesium on 1st, 3rd, 5th and then every five days during mechanical ventilation.

Main outcome measures. The primary outcome was the time to liberation from mechanical ventilation and secondary outcomes were complications: reintubation, tracheostomy, prolonged ventilation, or death.

Results. We find out that 100\% patients at admission had severe hypophosphatemia and $44 \%$ had low level of magnesium. Hypomagnesemia was treated until 10th day and level of phosphorus could not reach normal values until discharge. The presence of hypophosphatemia was associated with prolonged PICU admission (duration ratio 1.45, 95\% $\mathrm{Cl} 1.15$ to 2.25), and a higher risk of complications (OR 1.72, 95\% $\mathrm{Cl} 1.15$ to 2.52).

Conclusion. The presence of hypophosphatemia in children who were mechanically ventilated due to acute respiratory failure was associated with prolonged PICU admission and a higher risk of complications.

Trial registration: ISRCTN registry. Identifier: ISRCTN84734652.

Key words: children, mechanical ventilation, hypophosphatemia, hypomagnesemia.

\section{INTRODUCTION.}

Electrolyte disorders frequently develop in critically ill patients during the course of stay in pediatric intensive care unit (PICU). Phosphate and magnesium disturbances are one of those frequently encountered electrolyte disorders $1,6,7$. The incidence of hypophosphatemia is common in critically ill children might be from $42 \%$ at admission to PICU to over $60 \%$ during course of treatment 6 . Apart from this, magnesium deficiency commonly occurs in critical illnesses and correlates with higher mortality rate and worse clinical outcome in the intensive care unit (ICU) patients 1,2. Hypomagnesemia occurs in $40 \%$ of hospitalized patients, approximately $60 \%$ of postoperative patients, $65 \%$ of medical ICU patients, and up to $90 \%$ of surgical ICU patients. In addition, sick children, who are provided with mechanical ventilation, often have moderate or severe malnutrition together with deterioration of electrolyte levels and are at risk of refeeding syndrome with severe hypophosphatemia with life threatening complications. Well known, that all these lead to complicated weaning 
from mechanical ventilation. However, there is a little knowledge about impact of hypophosphatemia and low level of magnesium on long term outcomes in children on mechanical ventilation (MV).

The aim of this study was to investigate the prevalence of hypophosphatemia and low level of magnesium in children with acute respiratory failure. The study hypothesis was that the duration of stay in the intensive care unit in children depend on the degree of electrolyte disorders.

\section{METHODS}

Study design and setting. We complete the prospective single-center observational cohort study (July 2018 - July 2019) at the Department of Anesthesiology and Intensive Care, Danylo Halytsky Lviv National Medical University; Department of Anesthesiology and Intensive Care, Lviv Regional Children Hospital 'OCHMATDYT'. Ethical approval for this study (Ethical Committee $\mathrm{N}^{\circ} 1$ - 2018) was provided by the Ethical Committee of Danylo Halytsky Lviv National Medical University, Lviv, Ukraine (Chairperson Associate Professor Iryna Havrylyshyn) on 31 January 2018. Results described in this article is the part of the clinical study "Diaphragm ultrasound and trends in electrolyte disorders and transthyretin level as a method to predict ventilation outcome in children: the prospective observational cohort study"; ISRCTN84734652; https://doi.org/10.1186/ ISRCTN84734652.

Participants. We examined data of 31 patients at age 1 month -1 year, who needed invasive mechanical ventilation. In 4 patients we have no data of phosphorus level in blood. 27 patients were included in the study results analysis (fig.1). Participant inclusion criteria: presence of informed consent from legal representatives of the child to take part in trial; children aged 1 month -1 year; acute respiratory failure with clinical data of excessive work of breathing, laboratory data of hypoxemia, hypercapnia or both, acidosis which leads to need to provide invasive mechanical ventilation. Participant exclusion criteria: absence of informed consent from legal representatives of the child to take part in trial at any stage of this trial; acute or chronic respiratory failure without need to provide invasive mechanical ventilation; congenital heart diseases; neuromyotonia according to results of electromyography.

Variables. The primary outcome was the time to liberation from MV: every day from baseline the trialists checked the possibility of weaning patients from mechanical ventilation (its mean decreasing of parameters during mechanical ventilation and extubation - both together) and then take into account duration of mechanical ventilation. Secondary outcomes were complications: reintubation, tracheostomy, prolonged ventilation, or death (we check for the presence of these adverse events every day from baseline, then on day 28 of hospitalization and until the patient is discharged from the hospital).

Data sources/measurement. Levels of phosphorus and magnesium were obtained and measured spectrofotometrically in blood test samples on 1 st, 3rd, 5th and then every five days during MV.

Bias. We entirely try to avoid any type of bias which can occur in the planning, data collection, analysis, and publication phases of research.

Study size. We calculated that to achieve $90 \%$ power we needed 25 patients.

Quantitative variables and statistical methods. Statistical Package for the Social Sciences was used and the results were presented using median [IQR]

Table 1. Demographic and clinical characteristics of study population

\begin{tabular}{|c|c|c|c|}
\hline Variable & & No. $(n=27)$ & $\%(100.0)$ \\
\hline \multirow{2}{*}{ Age $(m)$} & Mean $\pm S D$ (Mediana) & $8.2 \pm 1.5(4)$ & \\
\hline & Range & $3-12$ & \\
\hline \multirow{2}{*}{ Sex } & male & 15 & \\
\hline & female & 12 & \\
\hline \multirow{2}{*}{ Weight (kg) } & Mean \pm SD & $6.8 \pm 4.2$ & \\
\hline & Range & $2.4-10.8$ & \\
\hline \multirow{2}{*}{ Length $(\mathrm{cm})$} & Mean \pm SD & $70.1 \pm 12.8$ & \\
\hline & Range & $52-84.5$ & \\
\hline \multirow{2}{*}{$\mathrm{BMI}\left(\mathrm{kg} / \mathrm{m}^{2}\right)$} & Mean \pm SD & $12,8 \pm 2,5$ & \\
\hline & Range & $7.2-18.8$ & \\
\hline \multicolumn{4}{|l|}{ Admission diagnosis } \\
\hline Acute heart failure & 1 & & $3.7 \%$ \\
\hline Sepsis & 4 & & $14.8 \%$ \\
\hline Septic shock & 5 & & $18.5 \%$ \\
\hline Malnutrition & 14 & & $51,9 \%$ \\
\hline Encephalopathy & 4 & & $14.8 \%$ \\
\hline Pneumonia & 23 & & $85.2 \%$ \\
\hline Acute obstructive bronchitis/bronchiolitis/asthma & 2 & & $7.4 \%$ \\
\hline Bronchopulmonary dysplasia & 2 & & $7.4 \%$ \\
\hline
\end{tabular}




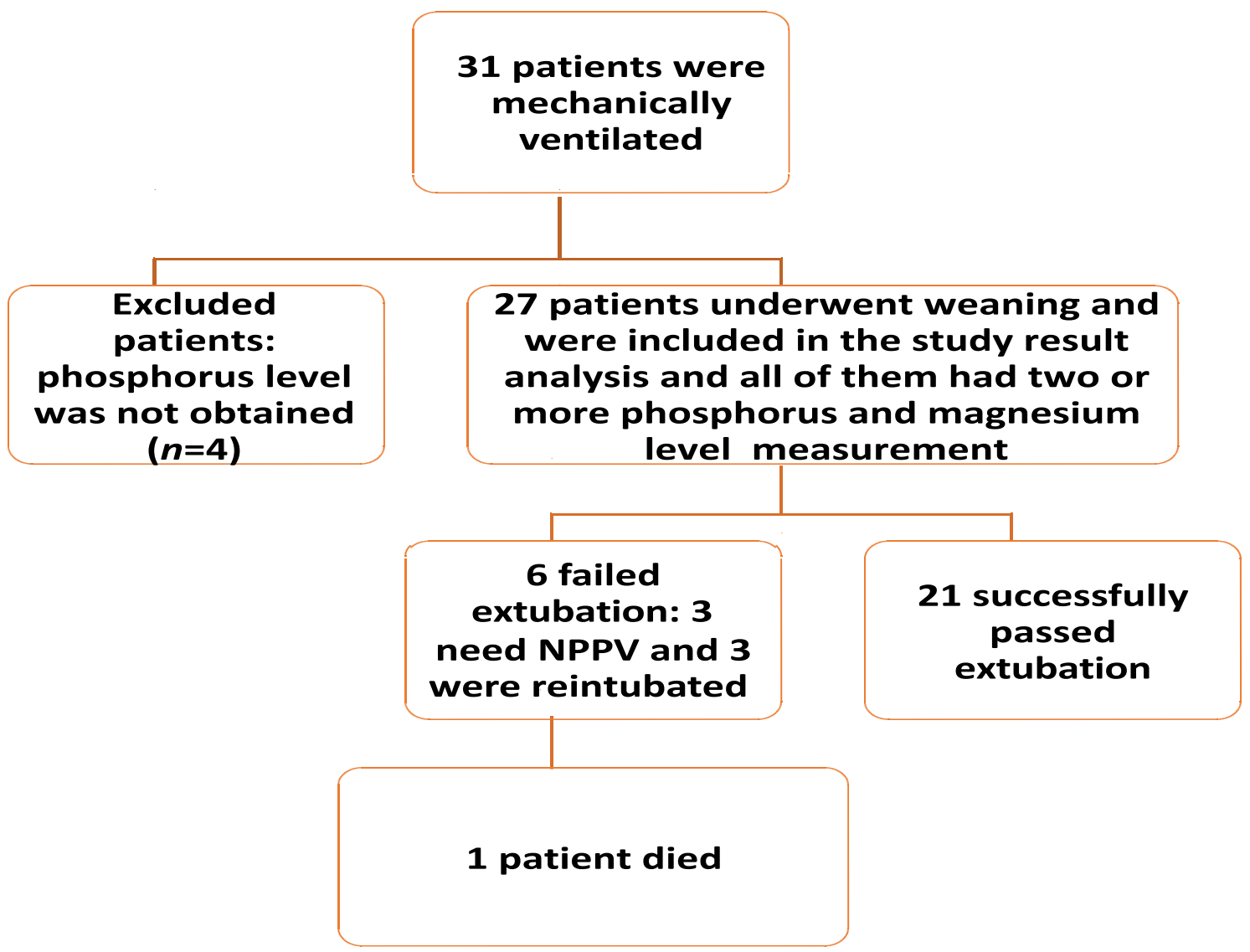

Fig. 1. A flow chart showing criteria of patients' selection and follow up through the study.

for non-normally distributed variables and as Mean \pm SD for normally distributed continuous variables, adjusted hazard ratio (HR), duration ratio and odds ratio (OR).

\section{RESULTS}

The flow of participants through the study is shown in Figure 1.

We examined 31 patients who were mechanically ventilated and excluded from study group 4 patients due to the fact that they had no obtained phosphorus level at admission. 27 patients underwent weaning and were included in the study result analysis and all of them had two or more phosphorus and magnesium level measurement. 21 patients were weaned from mechanical ventilation and 6 patients failed extubation: 3 need non-invasive positive pressure ventilation (NPPV) and 3 were reintubated. During the study period 26 patients of the studied group had been discharged and 1 patient died.

The demographic characteristics of the patients are shown in Table 1.

\section{SD - STANDARD DEVIATION.}

The average follow-up time was $17.4 \pm 2.1$ day and total amount was 2 weeks after discharge from PICU.
$100 \%$ of patients at day 1 st had severe hypophosphatemia $(0.11$ (0.18 to 0.06$) \mathrm{mmol} 1-1)$. The level of phosphorus (figure 2) increased up to 0.68 ( 0.57 to 0.92 ) mmol $1-1$ by median day 5 (IQR $5-10)$ and then to $0.76(0.72$ to 0.86$)$ mmol $1-1$ at day 10 th and to 0.79 (0.7 to 1.12$)$ on day 15 th.

Presence of hypophosphatemia was associated with prolonged ICU admission (duration ratio 1.45, $95 \% \mathrm{CI} 1.15$ to 2.25 ), and a higher risk of complications (OR 1.72, 95\%CI 1.15 to 2.52).

At admission, the incidence of low level of magnesium was $44 \% \quad(n=12)$ and incidence of normomagnesemia was $56 \%(n=15)$. While on third day the incidence of normophosphatemia was $78 \%$ $(n=21)$ and on fifth day it was $96 \%(n=26)$, (fig. 3, 4). After 5th day all patients had normal level of magnesium. Changes of magnesium level in those patients $(n=15)$, who were normomagnesemic at admission, had no significant changes during course of treatment and was $1.08 \pm 0.12 \mathrm{mmol} 1-1$ at $1 \mathrm{st}$ day, $1.01 \pm 0,18 \mathrm{mmol} \mathrm{l}-1$ at $3 \mathrm{rd}$ day and $0.94 \pm 0.07 \mathrm{mmol} \mathrm{1-1}$; $0.89 \pm 0.09 \mathrm{mmol} 1-1$ and $0.96 \pm 0.03$ at days 5th, 10th, 15 th .

There were no significant risks of complications due to deteriorations of magnesium level. However, 
1,2

Phosphorus level, mmol l-1

1

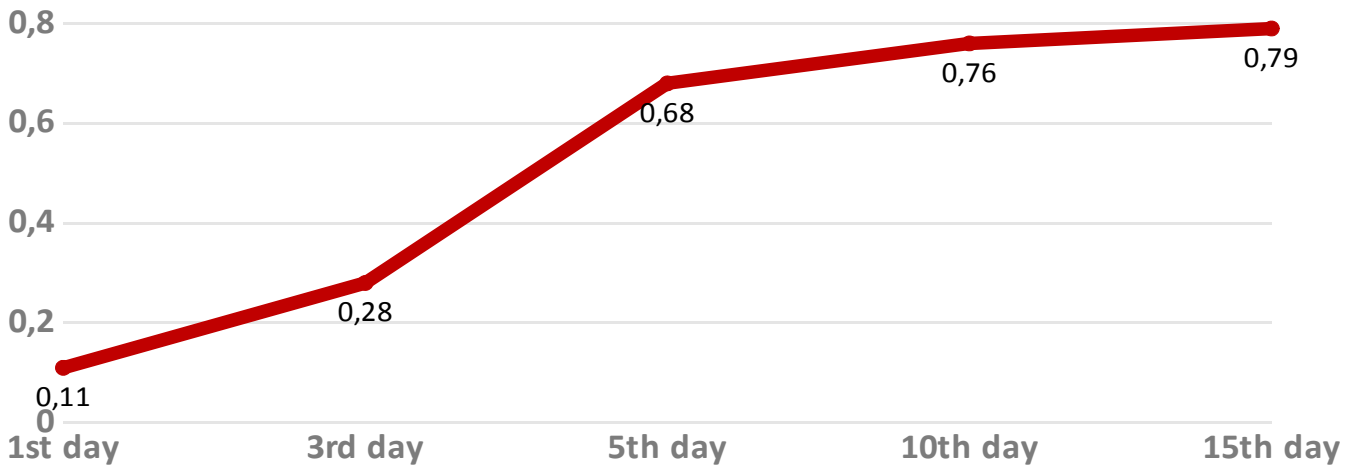

Fig.2. The dynamics of phosphorus level in mechanically ventilated patients $(n=27)$.

The incidence of low level of magnesium, \%

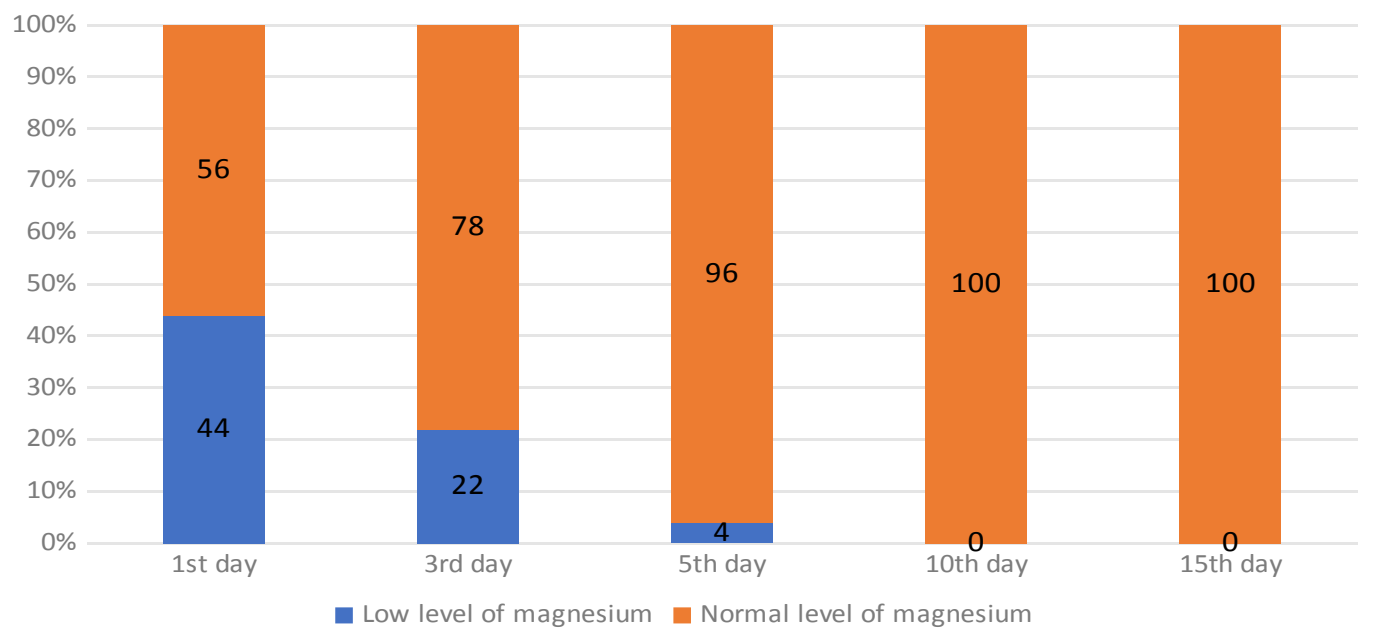

Fig. 3. The prevalence of hypomagnesemia in mechanically ventilated patients $(n=27)$.

the start of weaning from mechanical ventilation was prolonged in case of hypomagnesemia until the deteriorations were corrected. On the other hand, there are not available phosphorus-containing parenteral medication in Ukraine, therefore these changes in blood could not be fully corrected.

\section{DISCUSSION}

We set out to determine the prevalence of hypophosphatemia and low level of magnesium in children with acute respiratory failure and some limitation could be sporadic use of loop diuretics to achieve negative water balance or perioperative time without meal in children who need bronchoscopy or other surgery. However, analysis the dynamic of magnesium and phosphorus level according to the stages of the study give objective data to improve the sensitivity of estimation of this data. These findings were in agreement with a number of previous studies $1,2,3,5$ that show that magnesium deficiency commonly occurs in critical illnesses and correlates with higher mortality rate and worse clinical outcome in the intensive care unit patients.

In addition, in our research we find out that hypomagnesemia occurs in $44 \%$ at admission and was easily corrected by the 10th day of PICU treatment. It seems, that factors which might lead to magnesium level deterioration in mechanically ventilated patients 


\section{Magnesium level, mmol l-1}

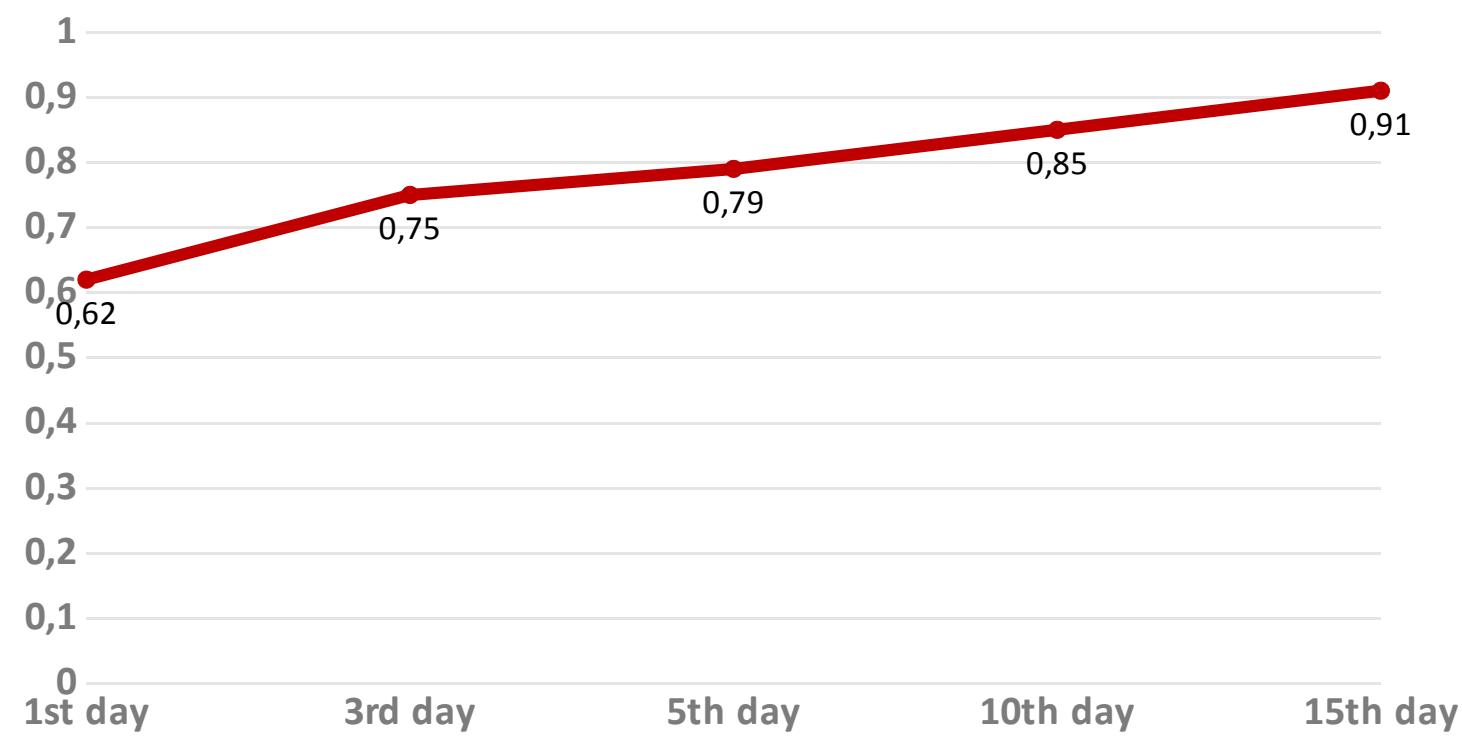

Fig.4. The dynamics of magnesium level in mechanically ventilated patients with hypomagnesemia at admission ( $n=12$ ).

were loop diuretics administration and eating processed food by breastfeeding women 2,4 . Other researchers found different hypomagnesaemia incidence, from $20 \%$ to $65 \%$ without significant relationship between magnesium levels and the number of days on mechanical ventilation or length of ICU stay 1 .

Furthermore, the main mechanisms which lead to magnesium level deteriorations are proton pump inhibitors, especially after long-term use. Impaired intestinal magnesium absorption, rather than renal absorption, seems to mediate the effect of proton pump inhibitors. Potential mediators include increased intestinal magnesium secretion, decreased active transcellular magnesium absorption, or decreased paracellular magnesium absorption 3 .

In our study we find out that there was no confirmation of significant risks of complications due to low magnesium level, however the start of weaning from mechanical ventilation usually was after correction of hypomagnesemia. Associated electrolyte abnormalities in our hypomagnesemic patients were hypophosphatemia which occurs in all of them $(100 \%)$.

all our patients $(100 \%)$ at 1 st day of treatment had severe hypophosphatemia. During course of treatment phosphorus level increased, however could not reach normal values until discharge from PICU. We received similar results with other researchers 6,7, that the presence of hypophosphatemia was associated with prolonged PICU admission and a higher risk of complications. However, there are difficulties in supplementation of phosphorus-containing parenteral medication in Ukraine. Therefore, this changes of phosphorus in blood could not be fully corrected at all. The only nutrition (enteral or "three-in-one formula" for parenteral feeding) might be the sources of phosphorus for our patients nowadays.

We suggest that in the future we will use the program with obligatory taking into account trends in electrolytes level to predict readiness time for weaning from mechanical ventilation readiness in critically ill children.

In summary, the presence of hypophosphatemia is associated with prolonged PICU admission and a higher risk of complications.

Conclusion. The prevalence of hypophosphatemia at 1 st day after admission was $100 \%$ and the prevalence of hypomagnesemia was $44 \%$. The presence of hypophosphatemia was associated with prolonged PICU admission and a higher risk of complications.

Конфрлікт інтересів: відсутній. Conflicts of interest: authors have no conflict of interest to declare. Надійшла до редакції / Received: 20.12.2019 Падіишла до редакції / Received: 20.12.2019 Прийнято до друку / Accepted: 13.01.2020

\section{REFERENCES}

1. Seyed Ali Javad Mousavi, Saeed Salimi, Mahdi Rezai. Serum Magnesium Level Impact on the Outcome of Patients Admitted to the Intensive Care Unit. Tanaffos Journal 2010; 9(4):28-33. http://www. tanaffosjournal.ir/en/archive.php?lrid $=240$

2. Baek Sung-Jin, Byeon Jung Hye, Eun So-Hee, Eun Baik-Lin, Kim Gun-Ha. Risk of low serum levels of ionized magnesium in children with febrile seizure. BMC Pediatrics 2018; 18:297-303. https://doi. org/10.1186/s12887-018-1271-z

3. Blaine J, Chonchol M, Levi M. Renal control of calcium, phosphate, and magnesium homeostasis. Clin J Am Soc Nephrol. 2015; 10(7):1257-72. doi: 10.2215/CJN.09750913. 
4. Won Hee Kim, Yoon Ha Kim, Yuna An, Jong Ho Moon, Eun Ji Noh Jong Woon Kim. Total and ionized serum magnesium and calcium levels during magnesium sulfate administration for preterm labor: Obstet Gynecol Sci $2018 ; 61(1): 56-62$. https://doi.org/10.5468/ ogs.2018.61.1.56

5. Kulpmann WR, Gerlach M. Relationship between ionized and total magnesium in serum. Scand J Clin Lab Invest Suppl 1996: 224:251-8. PMID:8865441
6. El Shazly AN, Soliman DR, Assar EH, Behiry EG, Gad Ahmed I. Phosphate disturbance in critically ill children: Incidence, associated risk factors and clinical outcomes. Ann Med Surg (Lond). 2017; 21:118-123. doi: 10.1016/j.amsu. 2017.07.079

7. Ahmed El Beleidy, Seham Awad El Sherbini, Hebat Allah Fadel Elgebaly, Arwa Ahmed. Calcium, magnesium and phosphorus deficiency in critically ill children. Egyptian Pediatric Association Gazette 2017; 65(2):60-64. https://doi.org/10.1016/j.epag. 2017.03.004

ФІЛИК О.В., ПІДГІРНИЙ Я.М.

ПОРУШЕННЯ ФОСФОРУ І МАГНІЮ У КРИТИЧНО ХВОРИХ ДІТЕЙ НА МЕХАНІЧНІЙ ВЕНТИЛЯЦІЇ ЛЕГЕНЬ: ПРОСПЕКТИВНЕ КОГОРТНЕ ОБСЕРВАЦІЙНЕ ДОСЛІДЖЕННЯ

Львівський національний медичний університет імені Данила Галицького

Вступ. Порушення рівня фосфору та магнію в сироватці крові є частими порушеннями у пацієнтів відділень інтенсивної терапії для дітей.

Метою роботи було вивчити поширеність гіпофосфатемії та гіпомагнеземії у дітей з гострою дихальною недостатністю. Робоча гіпотеза: тривалість штучної вентиляції легень та тривалість перебування на лікуванні у відділенні інтенсивної терапії для дітей залежать від наявності електролітних порушень.

Матеріали та методи дослідження. Дослідження проводилося на клінічній базі кафедри анестезіології та інтенсивної терапії Львівського національного медичного університету імені Данила Галицького у відділенні анестезіології та інтенсивної терапії Львівської обласної клінічної лікарні “ОХМАТДИТ” з липня 2018 року по липень 2019 року.

Пацієнти. Діти від 1 міс до 1 року, що потребували проведення інвазивної штучної вентиляції легень.

Інтервенції. Рівень фосфору та магнію вимірювали на 1-шу, 3-тю, 5-ту добу та надалі що 5 діб впродовж проведення штучної вентиляції легень.

Основні точки оцінювання. Первинною точкою оцінювання був час відлучення від штучної вентиляції легень, вторинними точками були ускладнення: реінтубація, трахеостомія, пролонгована штучна вентиляція легень, смерть пацієнта.

Результати. Нами встановлено що у 100\% пацієнтів при надходженні на лікування була тяжка гіпофосфатемія а у 44\% зниження рівня магнію в сироватці крові. Гіпомагніємію було скореговано до 10 доби лікування пацієнтів, тоді як рівень фосфору не вдавалося нормалізувати до переведення пацієнта із відділення інтенсивної терапії. Наявність гіпофосфатемії була асоційованою зі збільшенням тривалості лікування пацієнта у відділенні інтенсивної терапії для дітей (duration ratio 1.45, 95\% Cl 1.15 до 2.25) та з вищим ризиком виникнення ускладнень (OR 1.72, 95\% Cl 1.15 до 2.52).

Висновок. Наявність гіпофосфатемії у дітей з гострою дихальною недостатністю, що потребували проведення штучної вентиляції легень, була пов'язана з довшою тривалістю лікування у відділенні інтенсивної терапії та вищою частотою ускладнень. Реєстрація клінічного дослідження: ISRCTN registry. Identifier: ISRCTN84734652.

Ключові слова: діти, штучна вентиляція легень, гіпофосфатемія, гіпомагніємія.

\section{ФИЛЫК О.В., ПИДГИРНЫЙ Я.М.}

\section{НАРУШЕНИЕ ФОСФОРА И МАГНИЯ У КРИТИЧЕСКИ БОЛЬНЫХ ДЕТЕЙ НА МЕХАНИЧЕСКОЙ ВЕНТИЛЯ- ЦИИ ЛЕГКИХ: ПРОСПЕКТИВНОЕ КОГОРТНОЕ ОБСЕРВАЦИОННОЕ ИССЛЕДОВАНИЕ}

Львовский национальный медицинский университет имени Даниила Галицкого, Львов, Украина

Введение. Изменения уровня фосфора и магния в сыворотке крови являются частыми нарушениями у пациентов отделений интенсивной терапии для детей.

Целью работы было изучить распространенность гипофосфатемии и гипомагнеземии у детей с острой дыхательной недостаточностью.

Рабочая гипотеза: продолжительность искусственной вентиляции легких и длительность пребывания на лечении в отделении интенсивной терапии для детей зависят от наличия электролитных нарушений.

Материалы и методы исследования. Исследование проводилось на клинической базе кафедры анестезиологии и интенсивной терапии Львовского национального медицинского университета имени Данила Галицкого в отделении анестезиологии и интенсивной терапии Львовской областной клинической больницы “ОХМАТДЕТ” с июля 2018 по июль 2019 года.

Пациенты. Дети от 1 мес до 1 года, требовавших проведения инвазивной искусственной вентиляции легких.

Интервенции. Уровень фосфора и магния измеряли на 1-е, 3-е, 5-е сутки и в дальнейшем каждые 5 суток в течение проведения искусственной вентиляции легких

Основные точки оценивания. Первичной точкой оценки было время отлучения от искусственной вентиляции легких, вторичными точками были осложнения: реинтубация, трахеостомия, пролонгированная искусственная вентиляция легких, смерть пациента.

Результаты. Нами установлено, что у 100\% пациентов при поступлении на лечение была тяжелая гипофосфатемия а у $44 \%$ - снижение уровня магния в сыворотке крови. Гипомагниемию было скорректировано до 10 суток лечения , тогда как уровень фосфора не удавалось нормализовать к переводу пациента из отделения интенсивной терапии. Наличие гипофосфатемии было ассоциировано с увеличением продолжительности лечения в отделении интенсивной терапии для детей (duration ratio $1.45,95 \% \mathrm{Cl} 1.15$ до 2.25) и с высоким риском возникновения осложнений (OR $1.72,95 \% \mathrm{Cl} 1.15$ до 2.52 ).

Выводы. Наличие гипофосфатемии у детей с острой дыхательной недостаточностью, требующие проведения искусственной вентиляции легких, было связано с продолжительным лечением в отделении интенсивной терапии и высокой частотой осложнений

Регистрация клинического исследования: ISRCTN registry. Identifier: ISRCTN84734652.

Ключевые слова: дети, искусственная вентиляция легких, гипофосфатемия, гипомагниемия. 